\title{
Green Banking in Bangladesh: A Commitment towards the Global Initiatives
}

\author{
MD. MASUKUJJAMAN* \\ SERENA AKTAR ${ }^{* *}$
}

\begin{abstract}
:
Banks usually provide dedicated public services for profits. It is believed that profit should not be earned at the expense of the world's most pressing environmental problems. Thus the concept of green banking is evolved in response to the global initiative to save environment. It is a kind of welfare banking for the society at large, it responses to be green in daily operations and financing of nature conservation projects. The present paper aims to highlight the green banking road map in Bangladesh and the status of its implementation. Further, an attempt has been made to explore activities of commercial banks in comparison with global green banking initiatives. The study utilized secondary data available from related websites, published reports and articles. The study concluded that Bangladesh is far behind their counterparts from the developed countries. But the general picture presents a transition to green banking in a consistent manner for most banks. By taking care of its infrastructure development and accelerating its existing green movements, banks can ensure sustainability for itself and greener world for communities.
\end{abstract}

Key Words: Climate Change, Sustainable Development, Global initiatives, Green Banking.

\section{INTRODUCTION}

The world has seen much focus on economic progress and mankind has made giant steps in its journey through time. The side-effects of the development process have, however, also been equally enormous-loss of biodiversity, climatic change, environmental damage, etc. Environmental issue such as, restoration of nature's face of beauty have also become more important as the world has progressed economically.

Senior Lecturer in Finance, Department of Business Administration, Northern University Bangladesh, Dhaka-1209, Email: masuk_iba111@yahoo.com.

** Assistant Professor in Management, Department of Business Administration, Northern University Bangladesh, Dhaka-1209, Email: serene7868@gmail.com 
Bangladesh is, a low carbon emitting country even among the developing countries ${ }^{\mathrm{i}}$, likely to be one of the worst sufferers of Global Warming. It is experienced that climate change has already enhanced the frequency and intensity of floods, droughts and cyclones in Bangladesh, and would have negative impact on water resources, land, crop agriculture and food security, fisheries and livestock, forestry and bio-diversity, and human health as well.

Banks hold a unique position in an economic system that can affect production, services, business and other activities through their financing activities and thus may contribute to removing polluted environment. The banks should go green and play a pro-active role to take environmental and ecological aspects as part of their lending and investment principle, which would direct industries to go for mandated investment for environmental management, use of appropriate technologies and management systems.

\section{CONCEPTUAL FRAMEWORK}

\section{Green Banking}

Green Banking means eco-friendly or environment-friendly banking to stop environmental degradation to make this planet more habitable. This comes in many forms. Providing innovative green products: using online banking instead of branch banking, paying bills online instead of mailing them, purchasing green mortgage, opening up of CDs, green credit cards and money market accounts at online banks instead of large multi-branch banks or finding the local bank in your area that is taking the biggest steps to support local green initiatives. Green Banking is also a multi-stakeholders' endeavor where banks have to work closely with government, NGOs, International Financial Institutes (IFIs)/International Government Organizations (IGOs), Central Bank, consumers and business communities to reach the goal.

A Green Banking is an ethical banking/ social banking ("banks with a conscience"-Benedikter, 2011) as there is a strong building block which is corporate social responsibility (CSR) within the agenda of green banking. CSR bind banks in a relation with society/people showing the caring face of it in different situation, especially, in crisis period. Furthermore, Green Banking is regarded as sustainable banking, which has a role to safeguard the planet from environmental degradation, with the aim of ensuring economic growth which is sustainable $\mathrm{e}^{\mathrm{iii}}$. 
FIGURE-01: Some Green Banking Slogans of Banks

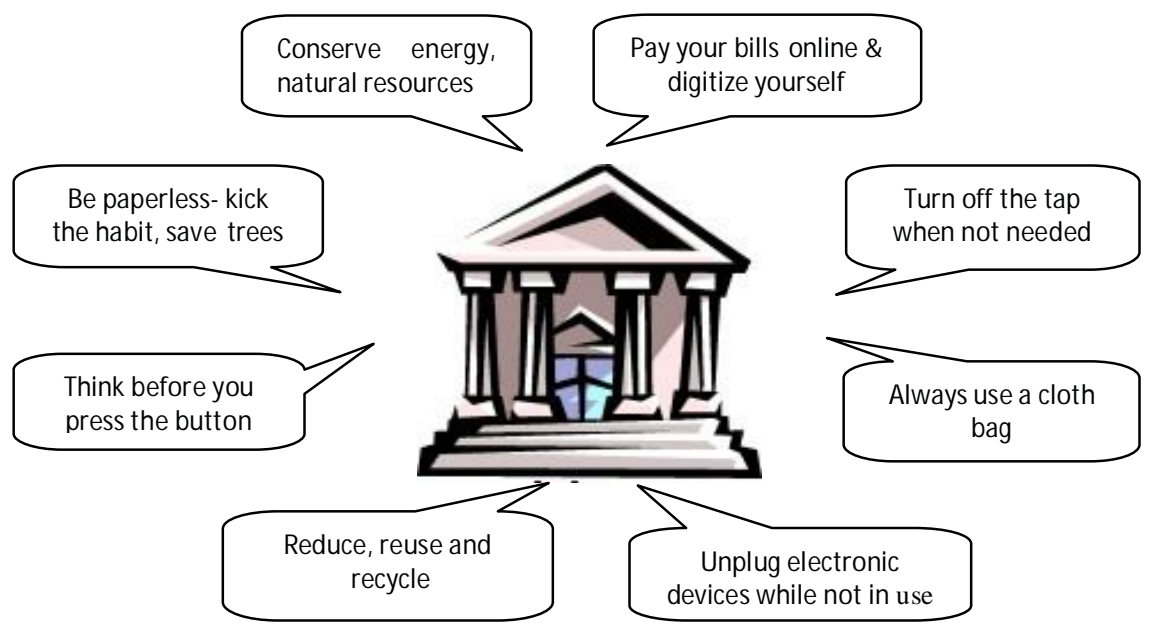

Source: Green Banking Activities, 2012

\section{Global Green Banking Initiatives:}

Based in Eustis and Clermont Florida USA, First Green Bank is the first bank of its kind to promote positive environmental and social responsibility while operating as a traditional community bank providing excellent service to investors and clients. The progressive approach to the community and the Earth sets it apart from other banks (Bhal, Sarta, 2012). The following are the quite a number of successful examples of banks worldwide towards sustainable finance (UNEP 2011).

Reduction of

Carbon emission

\& Saving of

Natural resources
IndusInd Bank, India has initiated its Green Office Project under which it has installed solar powered ATMs in different cities targeting energy saving as well as reducing $\mathrm{CO}_{2}$ emissions. State Bank of India (SBI) owns wind farms for generation of green power to partly substitute consumption of thermal power by its offices in Tamil Nadu, Maharashtra and Gujarat. Bank of America has a goal is to reduce its global greenhouse gas (GHG) emissions by an aggregate 30\% over 2004 levels; also it has a paper procurement policy which curtails the virgin wood fiber content of the paper it purchases. Besides, the bank is also helping employees reduce their emissions by 
providing US $\$ 3,000$ reimbursement to employees who buy a new hybrid, natural gas or electric vehicle. Hongkong and Shanghai Banking Corporation (HSBC) has established a series of environmental targets to be met on an annual basis, involving the reduction of waste, $\mathrm{CO} 2$ emissions, energy and water consumption. It has separate targets for data centers', paper consumption and business air travel. Banco Bilbao Vizcaya Argentaria (BBVA) Spain, a multinational Spanish banking group, has devised a Global Eco-efficiency Plan 2008-2012, which includes certain reduction plan (by percentage per employee) in energy use (2\%) in water (7\%), paper $(10 \%)$ and $\mathrm{CO} 2$ emissions (20\%). In addition to a $20 \%$ increase of people working in buildings with ISO 14001certification. Banco Itaú, Brazil, recycles 2,200 tons of shredded paper annually. Itau-Unibanco has introduced a Green Information Technology Program featuring the installation of videoconferencing facilities, substitution of computer monitors at the end of their useful life for the more efficient Liquid-Crystal Display (LCD) models and the correct disposal of obsolete electronic equipment. State Bank of India has launched some Point of Sale (POS) terminal in West Bengal where customer can deposit and withdraw money being paper less. (Thombre, Arjunrao, Kailash, 2011). In Columbia, Banco de Colombia was held responsible for cleaning up a site received from the National Federation of Cotton Growers in payment of a loan.

Environmental Banks such as Royal Bank of Canada, Industrial policy Development Bank of Turkey and Société Générale, France, have formulated an environmental policy for their institutions.

Environmental Risk in Core Risk

Standard Chartered, UK, evaluates and mitigates social and environmental risks across its lending, debt and capital markets activities, project finance and advisory work. Potential business deals are reviewed against the bank's position statements (child labor, climate change, gaming and gambling and water) covering sectors with high risk for environmental or social impact. It has developed sector-specific risk assessment tools 
(comprising a series of questions related to a client's operations and ability to manage environmental and social risks) are designed to provide relationship between managers and credit officers with a simple means of assessing clients' environmental, social and reputational risk performance.

Green Finance, investment \& Purchases
At the Sumitomo Mitsui Trust Holdings, Japan, the corporate banking unit looks after environmental screening of loans, while Bank Indonesia put environmental factors as part of consideration for credit application. Triodos Bank, Netherlands, set up with the objective of sustainable banking where the bank finances only enterprises which add social, environmental and cultural value - in fields such as renewable energy, social housing, complementary health care, fair trade, organic food and farming and social business. The bank was also the first to launch a 'green fund' for funding environment friendly projects (Dash 2008). Development Bank of Japan (DBJ) provides eco-rating projects with low interest rate and loan expansion facility. State Bank of India, Punjab National Bank \& IDBI Bank have begun to fund renewable energy projects. Foreign banks in India such as Standard Chartered and ABN Amro are also focused on renewable energy financing. ICICI Bank India has provided financial assistance to projects or clean technologies that specifically promote energy efficiency, renewable energy, biomass cogeneration, biomass gasification, waste heat recovery etc. While Bank of Baroda, India, has launched a scheme for financing SMEs for acquisition of equipments, services and adopting measures for enhancement of energy efficiency/conservation of energy. National Australia Bank and Canadian Imperial Bank of Commerce (CIBC) have taken a policy about their lending and investment activities are more diverse and range from incorporating the environmental factor into their business strategies to assessing the environmental risk of projects, to providing incentives to customers for adoption of environmentally responsible practices through so-called 'green financial products'. 
Green Products

ICIC Bank India \& Yes Bank India have projects portfolio in the areas of alternative energy and clean technologies as well as investments in the South Asia Clean Energy Fund and the Tatva Investment Program. At the Sumitomo Mitsui Trust Holdings, Japan, the asset management unit provides sustainable investment funds such as the China stock socially responsible investment (SRI) fund and an SRI fund which specializes in biodiversity issues.

National Australia Bank and CIBC Canada are following green procurement practices and considering the environmental performance of suppliers, distributors and subcontractors while making their purchases.

\section{Green Products}

Standard Chartered Banks have developed special green products and services encompassing the entire range of their activities, i.e. retail banking, SME lending, corporate lending, project finance and investment banking. For example, Industrial Bank of China has developed Energy Conservation and Emission Reduction Project Loans, a Low-Carbon Credit Card, Green Wealth Management Services and Green Financial Leasing Services; Bank of Tokyo-Mitsubishi UFJ, Japan offers eco-action business loans at preferential interest rates to SME customers who have acquired ISO 14001 certification. Bancoldex, Colombia has created a sustainable development credit line for companies seeking to prevent and mitigate their environmental impacts. SBI also has a new Green Home Loan scheme to support environmentally-friendly residential projects. The scheme offers concessions such as 5\% concession in margins, $0.25 \%$ concession in interest rate and zero processing fees for projects rated by the Indian Green Building Council (IGBC).

Environmental

Piraeus Bank in Greece works with environmental, consultancy service: national and international NGOs which provide insight and expertise on sustainability and environmental management issues, which helps the bank in sustainability management. 


\section{RESEARCH METHODOLOGY}

The present study is of analytical and conceptual in nature based on the secondary data. The secondary data has been collected from various newspapers, magazines, internet and commercial banks websites, Bangladesh Bank websites and reviews etc. Additionally, different working papers, journals and articles have been pursued enriching the literature of the study. To find out various green banking practices nationally and internationally, the websites of the respective banks have been utilized and studied. An intensive desk research has been undertaken to collect published data. The collected data are analyzed in the perspective of progress and adequacy of green banking activities in Bangladesh compared to the global endeavors. Microsoft office package especially MS-excel have been used mostly for summarizing and illustrating the collected data systematically.

\section{GREEN BANKING INITIATIVES IN BANGLADESH}

Taking into account the adverse effects of climate change and progressive action worldwide, Bangladesh Bank, the central bank of Bangladesh, has shown a deep commitment towards the vision of green world through green initiatives. Thereby Bangladesh Bank itself appears to be an example for the financial sector by performing some green banking activities for its head office and branch office management. These activities certainly convey a strong message to the financial institutions about the seriousness of Bangladesh Bank in its green movement.

Bangladesh Bank's green activities are concentrated in term of in-house and other than in-house activities. The word 'in-house activity' refers to domestic or activities limited to the office building related to network expansion, office automation and daily green operation etc. Under the networking program, all the departments of Bangladesh Bank head office and its nine branch offices have already been brought under a computer network (LAN/WAN), connecting almost 3,100 PCs as of March 31, 2012. Banks have been brought under the purview of E-Commerce with a view to providing the customers with online-banking facilities covering payments of utility bills, money transfer, and transactions in local currency through internet. 
FIGURE-02: In House Green Activities of Bangladesh Bank.

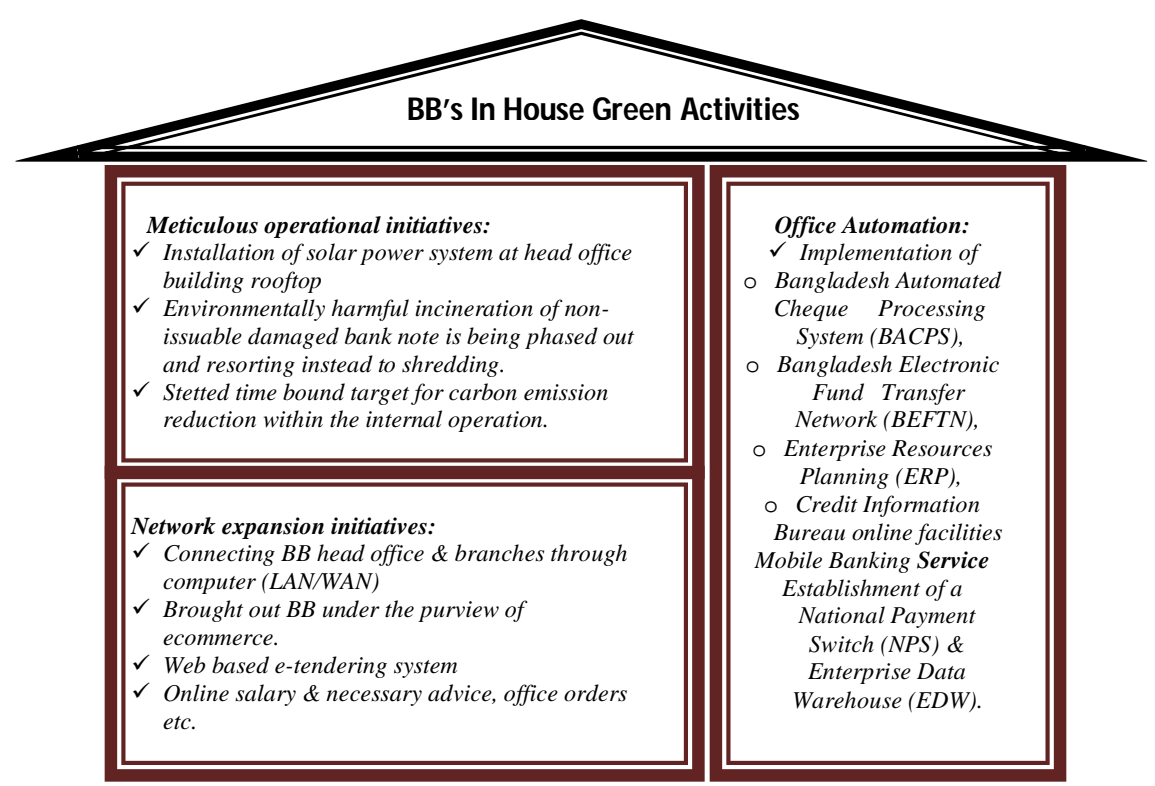

Source: Bangladesh Bank-Green Banking Report, 2012

Besides, Bangladesh Bank has taken the lead position in encouraging and implementing IT based technologies in the overall banking sector. The implementation of the Bangladesh Automated Cheque Processing System (BACPS), Bangladesh Electronic Fund Transfer Network (BEFTN), Enterprise Resources Planning (ERP), Credit Information Bureau online facilities, and Mobile Banking Service are worth mentioning. Establishment of a National Payment Switch (NPS) is also a major driving force for the whole payment system. In addition, Bangladesh Bank with its network package is now activated on a web based e-tendering system, which covers announcement of tender, distribution of schedules, bidding etc., to ensure simplicity and transparency of the tendering process. Online salary and other necessary advice, personnel file updated information, office orders, notification about on-line balance statements for all members or employees of Bangladesh Bank, an electronic pass for visitors and many more such conveniences are instantly available.

In other than in-house activities of Bangladesh Bank, it includes only refinance scheme. Bangladesh Bank has launched a refinance program in 2011 and as of 2012 it disbursed (Table-1) about Taka 2 billion in various sectors at only 5 percent interest rate. As electricity shortage is the major problem in a developing country like Bangladesh, the bank gives an emphasis on alternative energy like 
solar home system, solar pumping station, and solar PV module assembling plant. While Bio-gas, Effluent Treatment Plant, and Hybrid Hoffman Kiln schemes are funded as energy efficiency has received significant attention around the globe.

TABLE-1

AMOUNT DISBURSED UNDER REFINANCE SCHEME BY BB

\begin{tabular}{|l|c|}
\hline & April, 2012 (in Million Tk.) \\
\hline Solar irrigation pumping station & 18.87 \\
\hline Solar home system & $\mathbf{5 9 . 8 6}$ \\
\hline Bio-gas & 132.41 \\
\hline Effluent Treatment Plant (ETP) & $\mathbf{2 6 . 9 6}$ \\
\hline Hybrid Hoffman Kiln (HHK) & $\mathbf{2 0 . 0 0}$ \\
\hline Solar PV module assembling plant & $\mathbf{2 4 8 . 8 0}$ \\
\hline
\end{tabular}

Source: Bangladesh Bank-Green Banking Report, 2012

\section{Green Banking Road Map for Commercial Banks:}

The condition of climate is worsening at a greater pace and with a lot of diversity. Thereby only bearing green placard is not sufficient for banks. For this, banks will require a well-structured and transparent policy framework as well as long-term strategy. Bangladesh Bank is the first central bank in the world which has taken real initiatives, according to a definite agenda in its vision and mission to play a specific role in green banking (Bangladesh Bank, 2012). As a part of indicative initiatives, it issued circular on 'Policy Guidelines for Green Banking' where road map is rolled out in 3 phases which are expected to be completed by December 31, 2013. (Bangladesh Bank, 2011). Bangladesh Bank (BB) also offered some benefits like additional point in CAMELS rating (under management component) and disclosure of the name of top ten green banks each year, and will take into account these to give it permission to open new branches.

\section{Phase-I (Foundation):}

As per Bangladesh Bank guidelines, banks are required to formulate and adopt a broad environmental or Green Banking policy and strategy (approved by their Board of Directors or other high powered committee) and show general commitment on environment through in-house performance. Policy formulation is given the first priority, because if policy is not there or if it is not approved by the competent authority, then the adaptation and implementation of Green Banking activities that are to be linked with and compliant with the phases will not be on track. 
In support of the policy governance, banks are directed to approve a considerable fund in their annual budget allocation and establish a separate Green Banking Unit or Cell within stipulated time. The responsibility of this cell is to design, evaluate and administer green banking related issues of the bank. A senior executive should be assigned with the responsibility of heading the unit. The unit will report to the high powered committee time to time.

FIGURE-03: The First Phase of the Implementation of Green Banking Initiatives.

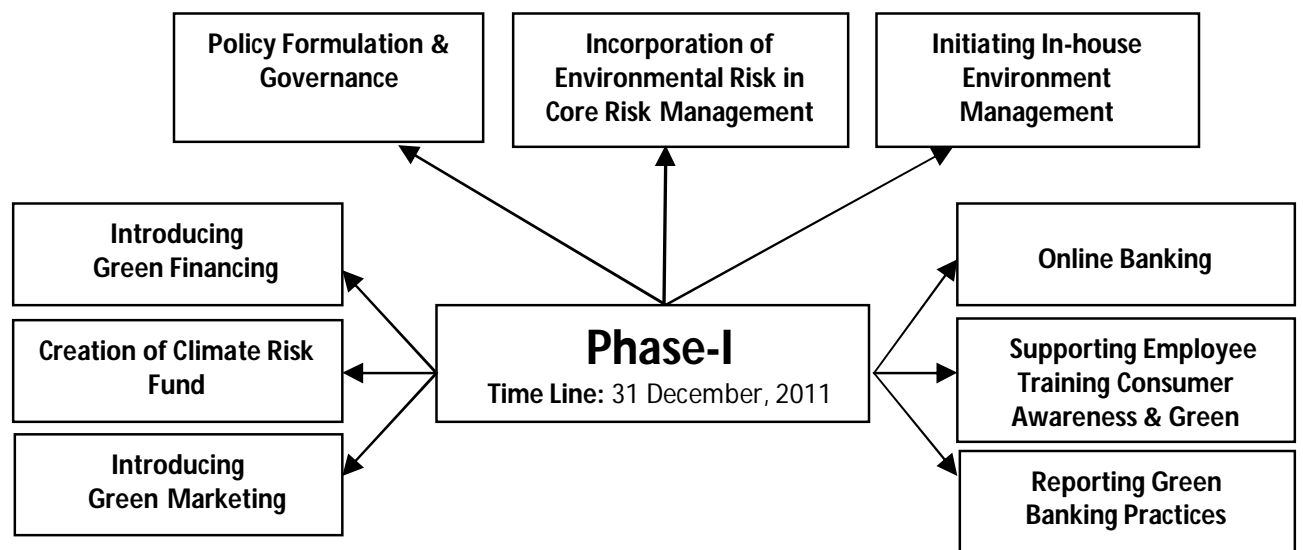

Source: Bangladesh Bank, BRPD Circular No.02, 2011

Banks are to comply with the instructions stipulated in the detailed guidelines on Environmental Risk Management (ERM) in consideration of a part of the Green Banking Policy. For ensuring improved lending policy and green lending, Banks need to incorporate Environmental and Climate Change Risk as part of the existing credit risk methodology prescribed to assess a prospective borrower. This will include integrating environmental risks in the checklists, audit guidelines and reporting formats.

Moreover, Bank should emphasize on making the easiest way to help environment by the practice of extended and improved online banking via a secure website of respective bank. This online banking can explore unique and convenient services to the clients eliminating paper waste, saving gas and carbon emission, reducing printing costs and postage expenses. Also banks have to come up with green marketing patronization and environmental awareness building program for its employees, consumers and mass people would be the continuous job under its public relation department. Simultaneously, it must report on the initiatives to $\mathrm{BB}$ and disclose in their respective websites. 


\section{Phase-II (Intensification):}

The phase II, which would not exceed December 31, 2012, sketches a scenario of consolidation of previous initiation with a subsequent bank specific environmental risk management plan and guideline, sector specific environmental policies and green strategic planning. A bank should develop and follow an environmental risk management manual or guidelines in their assessment and monitoring of project and working capital loans. They can also prepare standard and guidelines for themselves for improving Green Banking practices. Sectors specific policies to be framed for different environmental sensitive sectors such as agriculture and agro based business, construction and housing, engineering, basic metal and chemicals, manufacturing and service sectors, ships-breaking etc.

FIGURE-04: Figure Shows the Second Phase of the Implementation of Green Banking Initiatives.

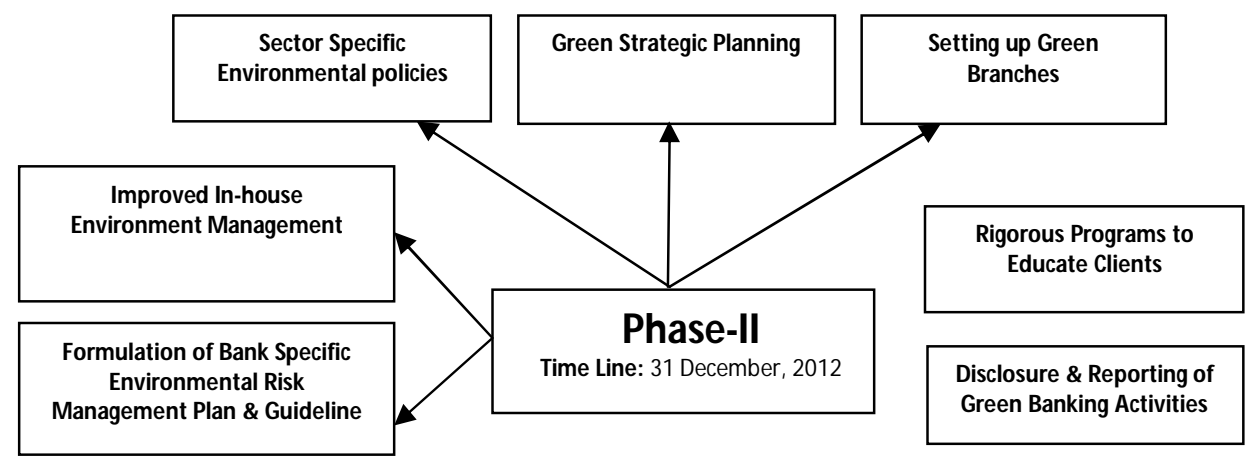

Source: Bangladesh Bank, BRPD Circular No.02, 2011

During the same period, a bank should determine a set of achievable green targets to be attained through strategic planning and disclose these in their annual reports and websites for green financing and in-house environment management as well. For in-house environment management, the target areas should cover attaining energy efficiency. And for Green Financing the target areas should cover reducing loans for certain environmentally harmful activities, attaining a particular percentage of environmental loans as percentage of total, introducing eco-friendly financial products etc.

For strengthening the first phase initiatives, banks are instructed to follow strategy of reuse, recycling of materials and equipments, and source reduction and waste minimization strategy should be part of in-house environmental 
management in Phase-II. In this connection, setting up green branches is encouraged where energy efficiency principles would be followed. In addition, a Green Branch will be entitled to display a special logo approved by Bangladesh Bank. Further, Banks should increasingly rely on virtual meeting through the use of video conferencing in lieu of physical travel which would help saving cost and energy. Moreover, as a part of pre-standardization action banks should start publishing independent green banking and sustainability reports showing past performances, current activities, and future initiatives. Updated and detailed information about banks environmental activities and performances of major clients should be disclosed.

\section{Phase-III (Diversification):}

A system of environmental management should be in place in a bank before the initiation of the activities of Phase-III. Bangladesh bank expects that banks will address the whole eco-system through environment friendly initiatives and introducing innovative products. Standard environmental reporting (Global Reporting Initiatives) with external verification should be part of the phase. The time lining for the actions to be taken under Phase-III should not exceed December 31, 2013.

FIGURE-05: The Third Phase of the Implementation of Green Banking Initiatives.

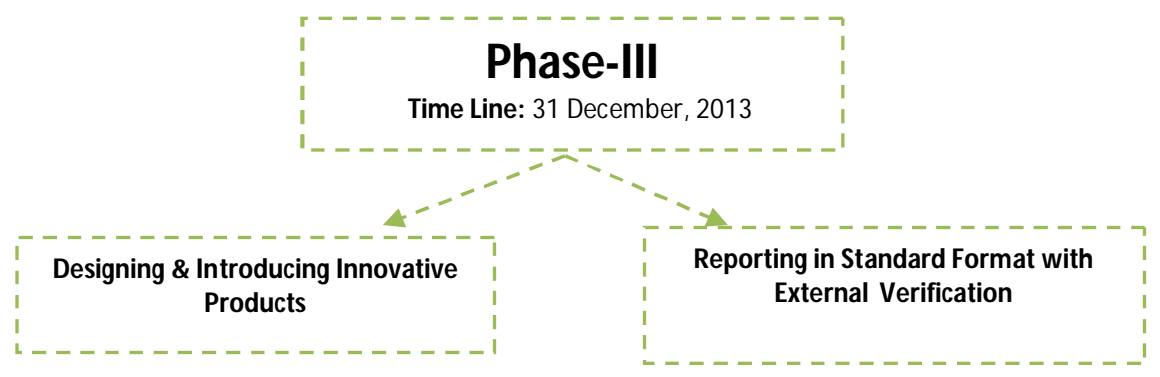

Source: Bangladesh Bank, BRPD Circular No.02, 2011

\section{IMPLEMENTATION STATUS OF GREEN BANKING ROAD MAP}

\section{Policy Formulation and Governance:}

According to the Figure-6, about $85 \%$ banks (out of 47 scheduled banks ${ }^{\text {iv }}$ as of September, 2012) have formulated their own Green Banking Policy Guidelines approved by their Board of Directors/competent authority, whereas the remaining $15 \%$ are yet to formulate their own policy for green banking. On the other hand, so far 43 banks (91\%) have formed a Green Banking Unit (GBU) 
for contributing to green banking activities, while 4 banks (9\%) are yet to establish GBU.

FIGURE-6: Bangladeshi Formations of Green Banking Policy and Unit.

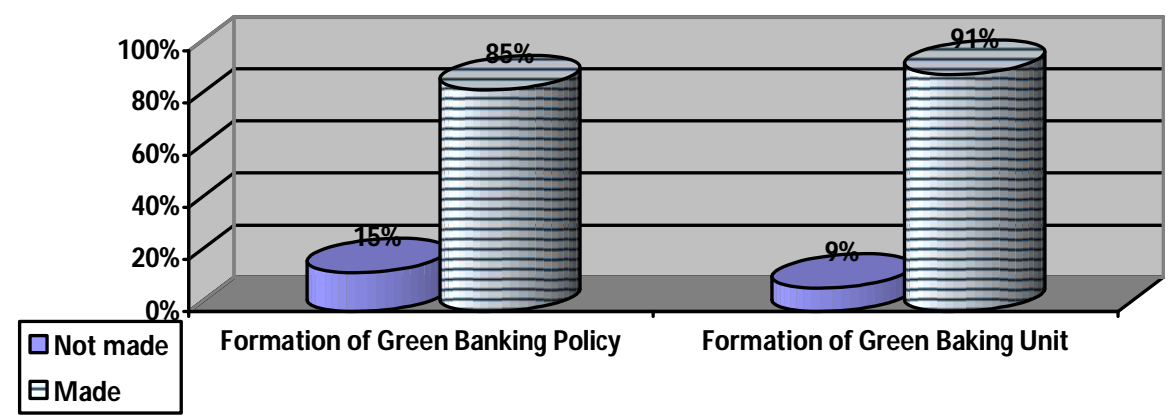

Source: Bangladesh Bank-Green Banking Report, 2012

\section{Green Financing:}

Banks have disbursed (Table-02) a total amount of Tk. 159,762.81 million as Green Finance. Out of this the maximum amount disbursed is in the projects having ETP (Tk.148,179.73 million) followed by the other projects (Tk. 5,517.70) and ETP (Tk.3,919.45 million).Banks have disbursed a lowest amount in bio-gas plant is Tk. 4.50 million.

TABLE-2

BANGLADESHI GREEN FINANCING IN VARIOUS PROJECTS IN MILLION TAKA BY COMMERCIAL BANKS (UP TO MARCH, 2012)

\begin{tabular}{|l|l|l|l|l|l|}
\hline Green Projects/Events & SCBs $^{\mathbf{v}}$ & PCBs & FCBs & SDBs & Total \\
\hline ETP & 77.68 & 3134.80 & 705.97 & 1.00 & $\mathbf{3 9 1 9 . 4 5}$ \\
\hline Projects having ETP & 5758.74 & 122694.64 & 19726.55 & 0.00 & $\mathbf{1 4 8 1 7 9 . 7 3}$ \\
\hline Bio-gas Plant, & 28.31 & 219.76 & 0.00 & 0.00 & $\mathbf{2 4 8 . 0 7}$ \\
\hline $\begin{array}{l}\text { Solar/Renewable } \\
\text { Energy Plant }\end{array}$ & 229.77 & 756.02 & 0.00 & 0.00 & $\mathbf{9 8 5 . 7 9}$ \\
\hline Bio-fertilizer Plant & 0.00 & 4.50 & 0.00 & 0.00 & $\mathbf{4 . 5 0}$ \\
\hline $\begin{array}{l}\text { Hybrid Hoffman Kiln } \\
\text { (HHK) }\end{array}$ & 112.40 & 795.17 & 0.00 & 0.00 & $\mathbf{9 0 7 . 5 7}$ \\
\hline Others & 5249.70 & 5.20 & 220.00 & 42.80 & $\mathbf{5 5 1 7 . 7 0}$ \\
\hline Total & $\mathbf{1 1 4 5 6 . 6}$ & $\mathbf{1 2 7 6 1 0 . 0 9}$ & $\mathbf{2 0 6 5 2 . 5 2}$ & $\mathbf{4 3 . 8}$ & $\mathbf{1 5 9 7 6 3}$ \\
\hline
\end{tabular}

Source: Bangladesh Bank-Green Banking Report, 2012 


\section{Environmental Risk Rating (EnvRR) in Core Risk Management (CRM):}

Complying with the BBs road map, Up to March 2012, EnvRR (Table-3) has been done for 7165 projects and 6896 projects $(96.2 \%)$ have been financed by banks. Banks have disbursed Tk. 504557.61 million for these projects. Among the different types of banks in Bangladesh, PCBs, FCBs has reached the mark of ninety percent and SCBs has financed the entire rated projects. The SCBs (BDBL-only contributor) has financed more than the rating they done.

TABLE-3

BANGLADESHI ENVIRONMENTAL RISK RATING BY BANKS

\begin{tabular}{|l|l|l|l|l|l|}
\hline & SCBs & PCBs & FCBs & SDBs & Total \\
\hline No. of projects rated & 47 & 6618 & 392 & 108 & 7165 \\
\hline $\begin{array}{l}\text { No.\& percentage of rated } \\
\text { project financed }\end{array}$ & $\begin{array}{l}47 \\
(100 \%)\end{array}$ & $\begin{array}{l}6383 \\
(96.45 \%)\end{array}$ & $\begin{array}{l}352 \\
(89.80 \%)\end{array}$ & $\begin{array}{l}112 \\
(103.7 \%)\end{array}$ & $\begin{array}{l}6896 \\
(96.2 \%)\end{array}$ \\
\hline $\begin{array}{l}\text { Total amount disbursed } \\
\begin{array}{l}\text { in favor of rated projects } \\
\text { (Million Tk.) }\end{array}\end{array}$ & 12164 & 1865.65 & 440165.3 & 50362.62 & 504557.61 \\
\hline
\end{tabular}

Source: Bangladesh Bank-Green Banking Report, 2012

\section{Online Banking:}

The online banking scenario (Table-4) looks promising, wherein 3042 out of 7998 branches $(38.03 \%)$ are equipped with online banking services. Thirty seven banks, mainly private and foreign commercial banks, are fully automated ensuring online banking services in each of their branches. $89.05 \%$ of the total branches of PCBs have been brought under online banking coverage. In the case of State Owned Commercial Banks (SCBs), about $5.49 \%$ of their total branches have been brought under online banking coverage, with Sonali Bank having comparatively a better scenario having $9.08 \%$ online coverage.

Banks have started to concentrate on mobile/SMS banking and internet banking. It shows from the returns that $3.91 \%$ and $1.42 \%$ of the total number of accounts have been facilitated with mobile/SMS banking and internet banking respectively. Most of the banks have been offering 24-hour banking services through their countrywide ATM booths. People have easy and instant access to banking services through using ATMs. Dutch-Bangla Bank Ltd. is taking the lead position with 1994 ATMs whereas Standard Charted bank Ltd. led the online banking (48.4\%) and mobile/SMS banking (cent percent) in Bangladesh. (See table-7, Appendix-A) 
TABLE-4

THE COVERAGE OF ONLINE BANKING IN BANGLADESH

\begin{tabular}{|l|l|l|l|l|l|}
\hline Types of Banks & SCBs & PCBs & FCBs & SDBs & Total \\
\hline Total Number of Branches & 3442 & 3078 & 63 & 1415 & 7998 \\
\hline Number of ATM owned & 64 & 3345 & 154 & 5 & 3568 \\
\hline $\begin{array}{l}\text { Number of Branches with online } \\
\text { banking facility }\end{array}$ & 189 & 2741 & 63 & 49 & 3042 \\
\hline $\begin{array}{l}\text { \% of branches with online banking } \\
\text { facility }\end{array}$ & $5.49 \%$ & $89.05 \%$ & $100 \%$ & $3.46 \%$ & $38.03 \%$ \\
\hline $\begin{array}{l}\text { \% of accounts facilitated with } \\
\text { internet Banking }\end{array}$ & $0 \%$ & $1.25 \%$ & $35.48 \%$ & $0 \%$ & $1.42 \%$ \\
\hline $\begin{array}{l}\text { \% of accounts facilitated with } \\
\text { SMS/Phone Banking }\end{array}$ & $0.06 \%$ & $4.52 \%$ & $53.70 \%$ & $0 \%$ & $3.91 \%$ \\
\hline
\end{tabular}

Source: Bangladesh Bank-Green Banking Report, 2012

\section{Branches Powered By Solar Energy:}

A total number of 101 branches of 18 banks are powered by solar energy as a part of in-house green initiative by commercial banks. 16 branches of Al-Arafah Islami bank and 12 branches of Islami Bank Bangladesh Limited are powered by solar energy. Some branches of Sonali, Eastern, BASIC, Dutch-Bangla, Shahjalal Islami Bank Limited are equipped with solar energy. Brac bank has facilitated 84 SME unit offices with solar/renewable energy. (See table-7, Appendix-A)

\section{Budget Allocation for 2012:}

In the response to Bangladesh Bank's instruction, (Figure-7) the highest percentage of banks allocated their fund is in marketing, training and development. About 34\% of banks have provided their allocation in green finance while it is $21 \%$ for climate risk fund and the rest of the banks did not allocate their fund in the year 2012.

FIGURE-7: Bangladeshi Implementation of Bangladesh Bank policy in allocation of budget

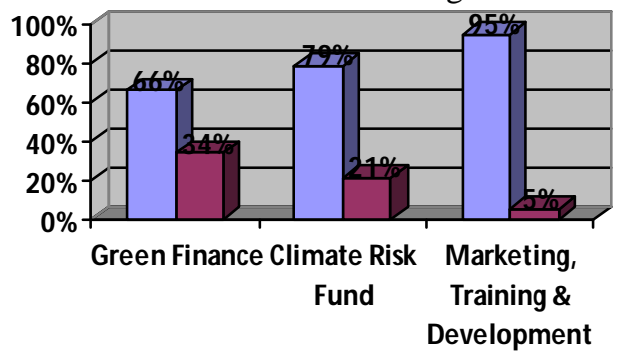

$\square$ No Allocation
$\square$ Have Allocation

Source: Bangladesh Bank-Green Banking Report, 2012 
Commercial banks (Table-5) have allocated Tk. 5252.07 million in their annual budget for 2012 where green finance is the significant amounting Tk. 5052.59 million. About Tk. 194.35 million and Tk. 5.13 million has allocated for Climate Change Risk Fund ${ }^{\mathrm{vi}}$ and marketing and capacity building respectively.

According to the bank's type-wise contribution towards green financing (Table-5), Private commercial banks allocated about Tk. 4042.01 million while state owned commercial bank, foreign commercial bank and specialized development bank have allocated about Tk.1160, Tk.30.03 and Tk.20 million respectively.

TABLE-5

Bangladeshi Budget Allocation in Million Taka for Green Banking For 2012

\begin{tabular}{|r|l|l|l|l|}
\hline $\begin{array}{r}\text { Types } \\
\text { of Banks }\end{array}$ & $\begin{array}{l}\text { Green } \\
\text { Finance }\end{array}$ & $\begin{array}{c}\text { Climate } \\
\text { Risk Fund }\end{array}$ & $\begin{array}{l}\text { Marketing, Training } \\
\text { \& Development }\end{array}$ & Total \\
\hline SCBs & 1160 & Nill & Nill & $\mathbf{1 1 6 0}$ \\
\hline PCBs & 3842.53 & 194.35 & 5.13 & $\mathbf{4 0 4 2 . 0 1}$ \\
\hline FCBs & 30.03 & Nill & Nill & $\mathbf{3 0 . 0 3}$ \\
\hline SDBs & 20 & Nill & Nill & $\mathbf{2 0}$ \\
\hline Total & $\mathbf{5 0 5 2 . 5 9}$ & $\mathbf{1 9 4 . 3 5}$ & $\mathbf{5 . 1 3}$ & $\mathbf{5 2 5 2 . 0 7}$ \\
\hline
\end{tabular}

Source: Bangladesh Bank-Green Banking Report, 2012

Improved In-House Environment Management:

Banks are required to improve their "In-house Environment Management" in the second phase in 2012. Banks are now concentrating on improving their inhouse green activities in accordance with their Green Office Guide. For example, banks are now increasingly relying on virtual meetings through the use of video conferencing in lieu of physical travel, which helps save cost and energy.

\section{Disclosure and Reporting of Green Banking Activities:}

In line with the guidelines of Bangladesh Bank, initiatives have been taken by banks for appropriate disclosure and reporting of green banking activities to Bangladesh Bank, Annual Report, Bank Web Site and Media. 


\section{Top Ten Green Banks in Bangladesh:}

The following banks have been graded as the top 10 banks on the basis of their overall Green Banking activities:

TABLE-06

TOP TEN BANKS (ALPHABETICALLY) IN THE YEAR, 2012

\begin{tabular}{|l|l|}
\hline Bank Asia Limited & Standard Chartered Bank Limited \\
\hline Dutch Bangla Bank Limited & Trust Bank Limited \\
\hline Eastern Bank Limited & Mutual Trust Bank Limited \\
\hline Islami Bank Bangladesh Limited & Pubali Bank Limited \\
\hline Shahjalal Islami Bank Limited & Prime Bank Limited \\
\hline
\end{tabular}

Source: Bangladesh Bank-Green Banking Report, 2012

Bangladesh bank has ranked the top ten banks based on their performance in implementation in each guideline provided by Bangladesh bank. In the top ten bank listed above Standard Chartered Bank Ltd., is only a foreign commercial bank, and rest of the banks are domestic private commercial banks including two Islamic shariah based banks namely IBBL and SIBL.

\section{CONCLUDING REMARKS}

As far as green banking is concerned Bangladeshi banks are far behind their counterparts from developed countries. The implementation status of the study highlights the fact that banks in Bangladesh are beginning to understand the importance of introducing green banking into their mainstream operations. Still, no bank in Bangladesh has been found in the UNEPs signatories of the Equator Principles $^{\mathrm{vii}}$ (which is regarded as one of the most important standards for responsible financing). The general picture presents a transition from some notable individual actions in a consistent and measurable environmental performance for most banks. According to this study, though the banking industry in Bangladesh are in the intensification phase passing through the foundation phase within the time frame, some banks are yet to stand on its feet. A few commercial banks are engaged in in-house environment management and are contributing towards environment friendly finance through their Green Energy Loans. However banks have a lot more scope to contribute and should make adequate investment in generating renewable energy. 
Banks should take initiative to set absolute Green House Gas emission reduction targets from operations, energy use and business travel. Banks should also be engaged in financing Clean Development Mechanism (CDM) projects. For this, awareness of development and advisory services by banks in the process of development of CDM projects will be crucial. Banks should also take steps to form Climate Risk Fund to finance the economic activities in the flood, cyclone and drought prone areas. In case of environmental risk rating, banks need to apply a quantitative approach for a more justified rating along with Environmental Due Diligence (EDD) Checklist under Subjective Criterion. They must speed up proper awareness and effective capacity building for the Board of Directors/competent authority/management at all levels of the banks/financial institutions and clients as well. They should take diversified activities especially introducing innovative products in the model of Bangladeshi infrastructure for a true green economy. Although Bangladesh have started its green journey lately, the hope is that a cooperative effort of banks and other stakeholders will contribute remarkably in coping with climate challenges and smoothen the path of sustainability in coming years. 


\section{REFERENCES}

African Institute of Corporate Citizenship (2004), Sustainability banking in Africa, ISBN 0-620-32746-4

Azam, Safiul (2012), Green corporate environment thru' green banking and green financing, available at

http://www.thefinancialexpressbd.com/more.php?news_id=135391\&date=2012 $-07-04$

Bangladesh Bank (2011), Policy Guidelines for Green Banking, available at http://www.bangladesh-

bank.org/mediaroom/circulars/brpd/feb272011brpd02e.pdf

Bangladesh Bank (2012), Green Banking Report, Green Banking and CSR Department.

Benedikter, R. (2011), Answers to the Economic Crisis: Social Banking and Social Finance, Spice Digest New York: Springer.

Bhal, Sarta, (2012 a), Green Banking-The New strategic imperative, Asian Journal of Research in Business Economics and Management, Vol.2, Issue 2, ISSN: 2249-7307.

Biswas N. (2011): Sustainable Green Banking Approach: The Need of the Hour, Business Spectrum, 1(1), 32-38

Dash R. N. (2008): Sustainable "Green" Banking: The Story of Triodos Bank, CAB Calling, October- December, 26-29

Equator Principles (2011), About equator principles, available at http://www.equator principles.com/index.php/about-ep/about-ep.

Goyal, K.A. and Joshi, Vijay (2011), A Study of Social and Ethical Issues in Banking Industry, International Journal Economic Research, ISSN: 2229-6158, 49-57

International Institute for Sustainable Development (2012): Sustainable Banking, available at http://www.iisd.org/business/banking, International Institute for Sustainable Development

Mallya, D., Prita (2012), Sustainable Banking in India: The Road Less Travelled, National Conference on Emerging Challenges for Sustainable Business 2012, ISBN - 978-93- 81583-46-3.

Millat K. M (2012), Green Banking Activities, Banking Regulation and Policy

Department Bangladesh Bank. Available at http://www.bb.org.bd/recentupcoming/news/oct022012newse_1.pdf

National Geographic (2007), Global Warming Fast Facts, Available at http://news.nationalgeographic.com/news/2004/12/1206_041206_global_warm ing.html. 
Rahman, Atiur (2012). Climate Change and Banking Sector of Bangladesh, seminar organized by BIBM. Available: http://www.bangladeshbank.org/governor/speech/feb082012gse.pdf

Schultz, Clark (2010), what is the meaning of green banking, Available at http://greenbankreport.com/green-bank-deals/what-is-the-meaning-of-greenbanking/

Thombre, Arjunrao, Kailash (2011), The New Face of Banking: Green Banking, Research Paper- Commerce, Vol.1, Issue.II, ISSN No-2032-5063.

UNEP (2011): UNEP FI Guide to Banking \& Sustainability, United Nations Environment Programme, Geneva, www.unepfi.org/

Wikipedia (2013), List of countries by carbon dioxide emissions, Available at http://en.wikipedia.org/wiki/List_of_countries_by_carbon_dioxide_emissions, November 03, 2013

\section{Websites:}

http://www.articlesbase.com/environment-articles/the-role-of-green-banking-inenvironmental-management-3437358.html [Accessed on February 08, 2013]

http://www.thedailystar.net/newDesign/news-details.php?nid=149676 [Accessed on February 15, 2013]

http://www.thefinancialexpress-bd.com/more.php?news_id=132169\&date=201206-08 [Accessed on December 22, 2012]

http://www.peblds.org/files/Publications/Articles/ECOFACT_Towards_green_ba nking.pdf [Accessed on March 03, 2013]

http://www.thedailystar.net/newDesign/news-details.php?nid=175809 [Accessed on March15, 2013]

http://www.shahjalalbank.com.bd/Green_Banking.php [Accessed on March 15, 2013]

http://www.indusind.com/downloads/Solar_atm_Launch.pdf [Accessed on March 03, 2013]

http://www.bangladesh-bank.org/fnansys/bankfi.php [Accessed on March 03, 2013] 


\section{Appendix-A \\ Table-6 \\ SOME EXEMPLARY WORKS OF COMMERCIAL BANKS IN BANGLADESH}

\begin{tabular}{|c|c|}
\hline \multirow{2}{*}{$\begin{array}{l}\text { Green Banking Activities } \\
\text { In-House Activities }\end{array}$} & \multirow[t]{2}{*}{ Banks } \\
\hline & \\
\hline Started Using energy saving bulbs & $\begin{array}{l}\text { Islami Bank Bangladesh } \\
\text { Ltd.(IBBL) }\end{array}$ \\
\hline Setting up Solar Panel on rooftop & $\begin{array}{l}\text { Mutual Trust Bank Ltd., } \\
\text { Islami Bank Bangladesh } \\
\text { Ltd. }\end{array}$ \\
\hline Launched Solar powered ATM booth & Bank Alfalah \\
\hline Use of Video/Audio conference in lieu of physical travel & Bank Asia Ltd. \\
\hline Acceptance of utility bill through internet & $\begin{array}{lll}\text { Commercial } & \text { Bank of } \\
\text { Ceylon PLC } & \end{array}$ \\
\hline $\begin{array}{l}\text { Taken Earth Hour at branches and head office where one officer } \\
\text { for each floor at HO and in every branch will be nominated as } \\
\text { "Green Monitor". }\end{array}$ & \multirow[t]{2}{*}{$\begin{array}{l}\text { Mutual Trust Bank Ltd. } \\
\& \text { Arab Bangladesh } \\
\text { Bank }\end{array}$} \\
\hline Other Than In-House Activities & \\
\hline $\begin{array}{l}\text { Preference to environmental infrastructure projects like renewable } \\
\text { energy, clean water supply project, waste water treatment }\end{array}$ & $\begin{array}{l}\text { Islami Bank Bangladesh } \\
\text { Ltd }\end{array}$ \\
\hline $\begin{array}{l}\text { Financed project of Bio-gas plants with power generation, bio- } \\
\text { fertilizer. }\end{array}$ & $\begin{array}{l}\text { Mutual Trust Bank Ltd. } \\
\& \text { IBBL \& Trust Bank }\end{array}$ \\
\hline $\begin{array}{l}\text { Launched 'MTB Krishi', a loan product to finance the core sectors } \\
\text { of agriculture, i.e., crops, fisheries, livestock, poultry and agro } \\
\text { equipments }\end{array}$ & Mutual Trust Bank Ltd. \\
\hline $\begin{array}{l}\text { Introduced Green Product: Krisan (for farmers in buying seeds, } \\
\text { fertilizer and arranging irrigation.), "Shobujayon" (for tree } \\
\text { plantation), "Kutir"( for handicraft and jute products), } \\
\text { "Rupantor" (for re-cycle industry), "Shobuj-Shokti" (for solar- } \\
\text { panel), "Shobuj Shilpo" (for industries in waste management). }\end{array}$ & $\begin{array}{l}\text { Shahjalal Islami Bank } \\
\text { Ltd }\end{array}$ \\
\hline $\begin{array}{l}\text { Financed Barguna Model' -A solar driven irrigation system in } \\
\text { Barguna, other solar irrigation projects. Hi-Tech Project for } \\
\text { 35KW Solar Power Plant at Gazipur. }\end{array}$ & Mutual Trust Bank Ltd. \\
\hline $\begin{array}{l}\text { Use of alternative delivery channel \& Ensuring maximum } \\
\text { recycling /processing of waste/detrimental by- products }\end{array}$ & $\begin{array}{l}\text { Bank Asia, Islami Bank } \\
\text { Bangladesh Ltd. }\end{array}$ \\
\hline $\begin{array}{l}\text { Financed Environment friendly projects Brick Field (Zig-Zag) } \\
\text { CNG Refueling projects, Organic Fertilizer, Jute Project instead } \\
\text { of Polythene }\end{array}$ & $\begin{array}{l}\text { Islami Bank Bangladesh } \\
\text { Ltd. }\end{array}$ \\
\hline Financed the first Compost Plant under CDM. & Dutch-Bangla Bank Ltd. \\
\hline $\begin{array}{l}\text { Developed a creative financial product called "EBL Nobodoy" for } \\
\text { generating electricity from poultry waste which will help prevent } \\
\text { environment pollution. }\end{array}$ & Eastern Bank Limited \\
\hline
\end{tabular}




\section{Appendix-B \\ TABLE-7}

GREEN BANKING POSITION OF BANGLADESHI COMMERCIAL BANKS

\begin{tabular}{|c|c|c|c|c|c|c|c|}
\hline $\begin{array}{l}\text { SL } \\
\text { no }\end{array}$ & Banks & \begin{tabular}{|c|} 
Green Budget \\
Allocation (In \\
millions) \\
For 2012
\end{tabular} & $\begin{array}{l}\text { Amount (mill. } \\
\text { tk.) of Green } \\
\text { Financing } \\
\text { Up to } \\
\text { March } 2012\end{array}$ & $\begin{array}{l}\text { No of } \\
\text { ATM } \\
\text { (Own) }\end{array}$ & $\begin{array}{c}\% \text { of a/c } \\
\text { facilitated } \\
\text { with Internet } \\
\text { Banking }\end{array}$ & $\begin{array}{c}\% \text { of branches } \\
\text { providing } \\
\text { online } \\
\text { banking } \\
\text { service }\end{array}$ & $\begin{array}{c}\% \text { of a/c } \\
\text { facilitated } \\
\text { with } \\
\text { Mobile/SMS } \\
\text { Banking }\end{array}$ \\
\hline & $\begin{array}{l}\text { State Owned Commercial } \\
\text { Bank }\end{array}$ & & & & & & \\
\hline 1 & Sonali Bank Ltd. & -- & 7591.34 & 52 & -- & $9.08 \%$ & -- \\
\hline 2 & Janata Bank Ltd. & 1160 & 1325.06 & 6 & -- & $0.46 \%$ & $0.06 \%$ \\
\hline 3 & Agrani Bank Ltd. & -- & 80.60 & 6 & -- & $7.59 \%$ & -- \\
\hline 4 & Rupali & -- & 24.59 .40 & -- & -- & $1.99 \%$ & -- \\
\hline & \begin{tabular}{|l|} 
Bangladesh Development \\
Bank
\end{tabular} & 1160 & 11456.40 & 64 & & & \\
\hline 5 & Bangladesh Krishi Bank & -- & -- & -- & -- & -- & - \\
\hline 6 & RAKUB & -- & -- & -- & -- & -- & -- \\
\hline 7 & BDBL & -- & 42.80 & -- & -- & -- & -- \\
\hline 8 & BASIC & 20 & 1.0 & 5 & -- & $100 \%$ & -- \\
\hline & Private Commercial Bank & 20 & & 5 & & & \\
\hline 9 & The City Bank & -- & 1278.49 & 123 & -- & $100 \%$ & $2.74 \%$ \\
\hline 10 & $\begin{array}{l}\text { United Commercial Bank } \\
\text { Ltd. }\end{array}$ & 500 & 8.41 .12 & 2 & -- & $100 \%$ & $0.06 \%$ \\
\hline 11 & Arab Bangladesh Bank Ltd. & -- & 9175.3 & 204 & $1.16 \%$ & $100 \%$ & -- \\
\hline 12 & IFIC Bank Ltd. & -- & 2264 & 3 & $1.95 \%$ & $100 \%$ & -- \\
\hline 13 & National Bank Ltd. & 37.50 & 20.30 & 0 & -- & $100 \%$ & -- \\
\hline 14 & Uttara Bank Ltd. & -- & 87.70 & 0 & -- & -- & -- \\
\hline 15 & Pubali Bank Ltd. & 500 & 18219 & 6 & -- & $75.37 \%$ & -- \\
\hline 16 & Eastern Bank Ltd. & 1.20 & 10422.9 & 2 & $17.38 \%^{\mathrm{h}}$ & $100 \%$ & $25.25 \%$ \\
\hline 17 & NCC Bank Ltd. & -- & 37.58 & 40 & -- & $100 \%$ & -- \\
\hline 18 & Dhaka Bank Ltd. & -- & 838.90 & 34 & $4.09 \%$ & $100 \%$ & $1.89 \%$ \\
\hline 19 & Southeast Bank Ltd. & -- & 11266.40 & 18 & $0.58 \%$ & $100 \%$ & -- \\
\hline 20 & Prime Bank Ltd. & 500 & 3087 & 100 & $1.74 \%$ & $100 \%$ & -- \\
\hline 21 & Dutch Bangla Bank Ltd. & 10 & 3625.74 & 1994 & $1.82 \%$ & $100 \%$ & $5.34 \%$ \\
\hline 22 & Mercantile Bank Ltd. & 88.3 & 22.84 & 22 & -- & $100 \%$ & -- \\
\hline 23 & One bank Ltd. & -- & 48.54 .83 & 20 & -- & $100 \%$ & -- \\
\hline 24 & Exim Bank Ltd. & -- & -- & 10 & $5.3 \%$ & $100 \%$ & -- \\
\hline 25 & Premier Bank Ltd. & -- & -- & -- & -- & $100 \%$ & $0.20 \%$ \\
\hline 26 & Standard bank Ltd. & -- & 7632.80 & 2 & $0.16 \%$ & $100 \%$ & -- \\
\hline 27 & First Security Bank Ltd. & -- & -- & 0 & -- & $100 \%$ & -- \\
\hline 28 & $\begin{array}{l}\text { Bangladesh Commerce } \\
\text { bank }\end{array}$ & -- & -- & 2 & -- & $16.67 \%$ & -- \\
\hline
\end{tabular}




\begin{tabular}{|c|c|c|c|c|c|c|c|}
\hline 29 & Mutual Trust Bank Ltd. & 16.38 & 53.37 & 93 & $1.04 \%$ & $100 \%$ & $0.43 \%$ \\
\hline 30 & Trust Bank Ltd. & 72.76 & 20 & 74 & $5.3 \%$ & $100 \%$ & $3.29 \% 0$. \\
\hline 31 & Bank Asia Ltd. & 35.0 & 22087.51 & 63 & $1.41 \%$ & $100 \%$ & $0.08 \%$ \\
\hline 32 & Al-Arafa Bank Ltd. & 500 & 48.134 & 10 & -- & $100 \%$ & -- \\
\hline 33 & ICB Islamic Bank Ltd. & 1.00 & 338.89 & 10 & -- & $100 \%$ & -- \\
\hline 34 & $\begin{array}{l}\text { Islami Bank } \\
\text { Bangladesh Ltd. }\end{array}$ & 592.37 & 26567.9 & 141 & $0.58 \%$ & $100 \%$ & $4.31 \%$ \\
\hline 35 & Social Islami bank Ltd. & 180.0 & 2040 & 10 & -- & $100 \%$ & -- \\
\hline 36 & Brac Bank Ltd. & -- & 128 & 305 & $2.74 \%$ & $100 \%$ & $19.07 \%$ \\
\hline 37 & Jamuna Bank Ltd. & -- & 186.80 & 57 & -- & $100 \%$ & $0.38 \%$ \\
\hline \multirow[t]{2}{*}{38} & Shahjalal Islami Bank Ltd. & 1007.50 & 1841.86 & 0 & -- & $100 \%$ & -- \\
\hline & $\begin{array}{l}\text { Foreign Commercial } \\
\text { Bank }\end{array}$ & 4042.01 & & 3345 & & & \\
\hline 39 & Commercial Bank of Celon & -- & 9.57 & 17 & $3.71 \%$ & $100 \%$ & -- \\
\hline 40 & \begin{tabular}{|l} 
Standard Chartered Bank \\
Ltd.
\end{tabular} & 21.38 & 12144 & 91 & $48.4 \%{ }^{\mathrm{t}}$ & $100 \%$ & $100 \%$ \\
\hline 41 & State Bank of India & -- & -- & 0 & $9.76 \%$ & $100 \%$ & -- \\
\hline 42 & Habib Bank & -- & -- & 5 & -- & $100 \%$ & -- \\
\hline 43 & National Bank of Pakistan & -- & 185 & 0 & -- & $100 \%$ & -- \\
\hline 44 & Citi Bank NA & -- & 6554 & 0 & $46.25 \%$ & $100 \%$ & -- \\
\hline 45 & $\mathrm{HSBC}$ & 8.65 & 1760 & 38 & $26.19 \%$ & $100 \%$ & -- \\
\hline 46 & Woori Bank & -- & -- & 0 & $7.6 \%$ & $100 \%$ & -- \\
\hline \multirow[t]{3}{*}{47} & Bank Al-Falah & 0.03 & -- & 3 & -- & $100 \%$ & -- \\
\hline & & 30.06 & 20652.52 & 154 & & & \\
\hline & Grand Total & 5252.07 & & 3568 & & & \\
\hline
\end{tabular}

Source: Bangladesh Bank-Green Banking Report, 2012 
${ }^{\mathrm{i}}$ The $\mathrm{CO} 2$ emission (kt) in Bangladesh (Rank-63) was reported at 46526.90 which is $0.15 \%$ of the global total in 2008, according to the World Bank. Carbon emission by other Developing countries like Brazil (Rank-17 \& $1.30 \%$ of global total), Mexico (Rank-11 \& 1.58\%), India (Rank-3 \& $5.78 \%$ of Global total) is significantly higher than Bangladesh. While the highest carbon emitter country are China (Rank-1 \& $18.11 \%$ of global total) and USA (Rank-2 \& $23.33 \%$ of global total). (Wikipedia, 2013)

ii According to Institute for Social Banking, "Social Banking describes the provision of banking and financial services that consequently pursue, as their main objective, a positive contribution to the potential of all human beings to develop, today and in the future". (Goyal. K.A. and Joshi Vijay-2011)

iii Sustainability stands for the precept of giving equal consideration to economic, ecological, and social aspects in all of our actions in order to achieve the goal of passing on a healthy environment, good business conditions and a socially just basis for life to coming generations. (AICC ,2004)

iv The number of scheduled bank and non scheduled banks are 52 and 4 respectively as on November 2013. (Bangladesh Bank)

${ }^{v} \mathrm{SCB}=$ State owned commercial bank $(\mathrm{N}=4), \mathrm{PCB}=$ Private commercial bank $(\mathrm{N}=30), \mathrm{FCB}=$ Foreign commercial bank $(\mathrm{N}=9), \mathrm{SDB}=$ Specialized development bank $(\mathrm{N}=4)$ as on September 2012. Though 10 new banks have been approved recently only 5 PCBs have started their operations.(Bangladesh Bank)

vi The Climate Risk Fund covers (i) Fund for part of CSR activities that are related to Climate Change Risk and (ii) Financing Project/Event related to Climate Change Risk (flood, cyclone and drought prone areas) at the regular interest rate without charging additional risk premium.

vii 'Equator Principles' (ten of the world's leading international banks announced the adoption of it in June 2003); a comprehensive set of environmental and social guidelines for the financing of projects over US\$50 million. These principles are based on the environmental and social safeguard policies and guidelines of the International Finance Corporation (IFC). The banks apply the principles globally to projects in all industry sectors. With rapid speed, these principles have become the new banking industry standard on environmental and social issues for project finance. As of May 2004, there are twenty three financial institutions that have adopted the Equator Principles. (Equator Principles, 2011). 